\title{
Ultrastructural Features of Chloride Cells in the Gill Epithelium of the Atlantic Salmon, Salmo salar, and Their Modifications During Smoltification
}

\author{
M. PISAM, P. PRUNET, G. BOEUF, AND A. RAMBOURG \\ Département de Biologie, Centre d'Etudes Nucléaires de Saclay, 91191 Gif-sur-Yvette, France
}

\begin{abstract}
To elucidate the ultrastructural modifications of the gill epithelium during smoltification, gills of the Atlantic salmon (Salmo salar) were examined by electron microscopy at three stages of this process, which were defined as follows: "parrs" were freshwater fish that had not yet started their transformation; "freshwater smolts" were freshwater fish that were ready to enter seawater; and "seawater smolts" were smolts that had been transferred from fresh water and maintained for 4 days in seawater $(35 \%)$.
\end{abstract}

In the gill epithelium of parrs, there were two types of chloride cells. The large chloride cells contained deeply stained mitochondria and numerous apical, irregular, dense, membrane-bound bodies that formed $77 \%$ of the chloride cell population and were distinguished easily from small chloride cells that have distinctly paler mitochondria and no dense bodies in their apical cytoplasm. In freshwater smolts, the large chloride cells formed $95 \%$ of the chloride-cell population. In contrast to the small chloride cells that were not modified, they almost doubled in size. Their tubular system developed extensively to form a tight network with regular meshes significantly smaller than those observed in parr chloride cells. Forty percent of the large chloride cells were associated with a new type of cell, the accessory cell, to which they were bound by shallow apical junctions. Half of these accessory cells were not seen to be in contact with the external medium. In seawater smolts, $80 \%$ of the large chloride cells were associated with accessory cells. Most accessory cells reached the external medium and sent numerous cytoplasmic interdigitations within the apical portion of the adjacent chloride cells. As a result, a section through the apical portion of the chloride cells and their associated accessory cells revealed a mosaic of interlocked cell processes bound together by an extended, shallow apical junction.

It was concluded that the Atlantic salmon develops in fresh water most of the ultrastructural modifications of the gill epithelium which in most euryhaline fish are triggered by exposure to seawater. The effective transfer into seawater would act only as a final stimulus to achieve some adequacy between the freshwater smolt and its new environment.

\section{INTRODUCTION}

In the gill epithelium of teleostean fish, the "chloride cells" have a major role in hydromineral regulation

(c) 1988 ALAN R. LISS, INC.
(Keys and Willmer, 1932; Philpott and Copeland, 1963; Maetz, 1971). Their morphological features vary with the salinity of the external medium. Thus, during adaptation of euryhaline fish to seawater, the chloride cells undergo hypertrophy (Karnaky et al., 1976a; Philpott, 1980; Pisam et al., 1987), and there is marked development of the intracytoplasmic membranous tubular system opening at the basolateral cell surface (Doyle and Epstein, 1972; Karnaky et al., 1976a; Philpott, 1980; Pisam, 1981). In addition, a new cell type, the "accessory cell," appears in the gill epithelium and sends interdigitations into the apex of the chloride cell (Hootman and Philpott, 1980; Laurent and Dunel, 1980); as a result, a multicellular complex is formed in which cells are interconnected by numerous, presumably permeable, short junctions (Sardet et al., 1979; Dunel-Erb and Laurent, 1980).

The Atlantic salmon, Salmo salar, during a given period of its life, also must adapt to seawater and therefore must rely on its gill epithelium to keep hydromineral equilibrium. In France, during its early life as a "parr," the salmon lives in fresh water; then, during the spring of its second year, the fish undergoes characteristic morphological, physiological, and biochemical transformations as it prepares to enter seawater (Hoar, 1976; Folmar and Dickhoff, 1980). These modifications are referred to as smoltification, and the fish prepared to pass into seawater is referred to as a "freshwater smolt."

The purpose of the present investigation is to describe the ultrastructural modifications of chloride cells and associated accessory cells during the smoltification process. The observations reveal that, before the smolt enters seawater to become a "seawater smolt," the gill epithelium undergoes marked transformations that heretofore have been observed only in seawater-adapted fish.

\section{MATERIALS AND METHODS}

Atlantic salmon (Salmo salar) of a Norwegian strain were obtained from the fish hatchery at "Le Conquet" in Brittany (France). The fish were reared in an Ewos tank $\left(4 \mathrm{~m}^{3}\right)$ supplied with fresh water: $\mathrm{Na}^{+}=1,48 \mathrm{mEq} /$ liter, $\mathrm{Ca}^{++}=0.65 \mathrm{mEq} /$ liter (flow rate: $1 \mathrm{~m}^{3} / \mathrm{hr}$ ) and fed on manufactured dry pellets by automatic feeder (ration: $2 \%$ body weight/day). The photoperiod was natural, and water temperature during the experimental period increased from 5 to $13^{\circ} \mathrm{C}$ in 1986 .

\footnotetext{
Address reprint requests to Dr. M. Pisam, Département de Biologie, CEN Saclay, 91191 Gif-sur-Yvette, Cedex, France.

Received October 7, 1987. Accepted June 4, 1988.
} 
Atlantic salmon smoltification study : Brest 1986

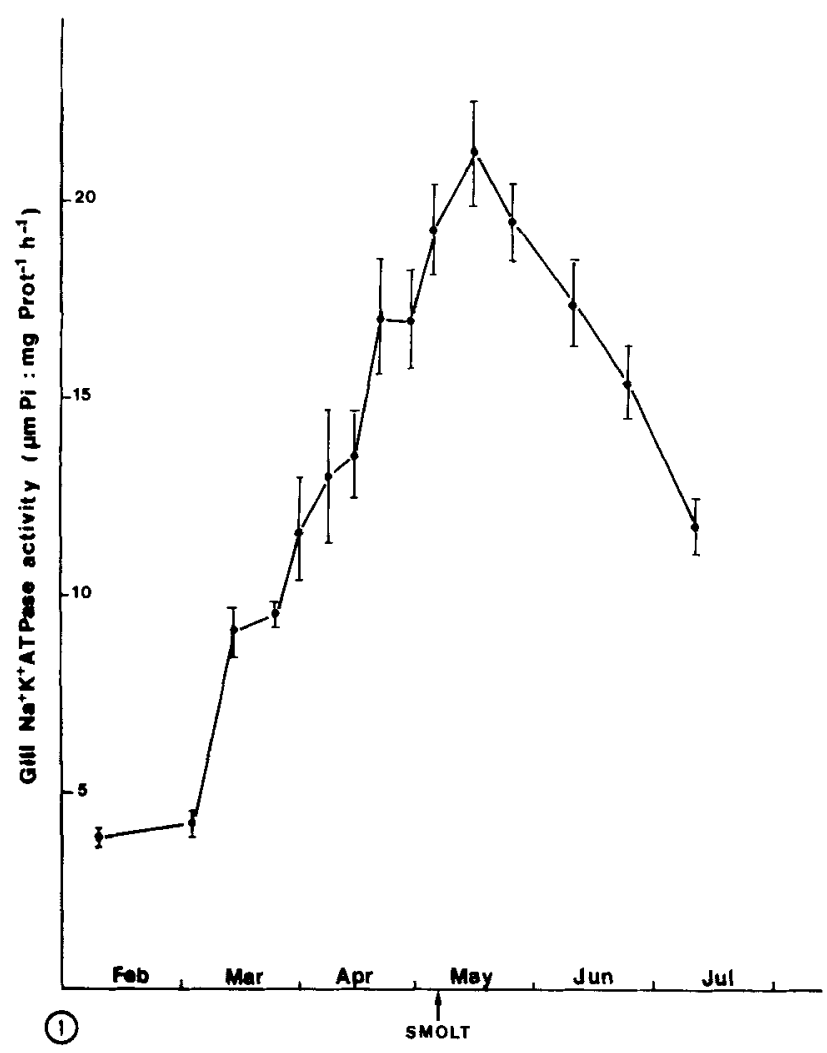

Fig. 1. Evolution of gill $\mathrm{Na}^{+}-\mathrm{K}^{+}$-ATPase activity in Salmo salar from February to July 1986.

Because only some of these Atlantic salmon underwent smoltification every spring, the ultrastructure of the gill epithelium in "parrs" and "smolts" could be studied in the same population.

Parrs have been identified according to their length at different sampling dates (March, June, and December 1986) following the technique described by Boeuf et al. (1985). Briefly, a histogram of the length of the fish population was obtained at each sampling date. Such histograms showed a classical bimodal distribution, and it was demonstrated that only fish belonging to the lower mode corresponded to parr (Thorpe et al., 1982;

$\begin{array}{ll} & \\ \text { A } & \text { accessory cell } \\ \text { C } & \text { chloride cell } \\ \text { ER } & \text { endoplasmic reticulum } \\ \text { G } & \text { Golgi apparatus } \\ \text { j } & \text { junction } \\ \text { LC } & \text { large chloride cell } \\ \text { m } & \text { mitochondria } \\ \text { MB } & \text { membrane-bound bodies } \\ \text { n } & \text { nucleus } \\ \text { P } & \text { pavement cell } \\ \text { SC } & \text { small chloride cell } \\ \text { SL } & \text { secondary lamella } \\ \text { T } & \text { tubular system } \\ \text { VT } & \text { vesicular tubular elements }\end{array}$

Boeuf et al., 1985) and thus were taken for ultrastructural examination.

As the gill $\mathrm{Na}^{+}-\mathrm{K}^{+}$-ATPase activity usually is recog. nized as a good criterion for the identification of various stages of smoltification (Saunders and Henderson, 1978; Boeuf et al., 1978; Folmar and Dickhoff, 1981), the evolution of this activity was followed in yearling Atlantic salmon taken from the upper mode of the population and maintained in fresh water during the year 1986. For each sampling date, 15 fish were starved for $24 \mathrm{hr}$ and then stunned by cranial concussion. Gill filaments taken from these fish were rinsed in $0.25 \mathrm{M}$ sucrose in $0.01 \mathrm{M}$ Tris-HCl, $\mathrm{pH} 7.4$, and frozen in liquid nitrogen. $\mathrm{Na}^{+}-\mathrm{K}^{+}$. ATPase activity for each fish was measured according to the method described by Lasserre et al. (1978): whole gill tissues were homogenized with a Polytron homogenizer for $10 \mathrm{sec}$ at full speed in $10 \mathrm{ml}$ sucrose solution $(0.25 \mathrm{M}$ sucrose in 0.01 Tris- $\mathrm{HCl}, \mathrm{pH}$ 7.4). The suspension was centrifuged at 3,000 $\mathrm{gm}$ for 20 min, and the supernatant was recentrifuged at 74,000 $\mathrm{gm}$ for $60 \mathrm{~min}$. The pellet obtained was rehomogenized and diluted in sucrose solution to reach a protein concentration of 1-4 $\mathrm{mg} / \mathrm{ml}$. Enzyme activity was measured in the presence or absence of ouabaine $\left(10^{-4} \mathrm{M}\right)$, in a medium containing $4 \mathrm{mM}$ ATP, $5 \mathrm{mM} \mathrm{MgCl}_{2}, 100 \mathrm{mM} \mathrm{NaCl}$, and $20 \mathrm{mM} \mathrm{KCl}$; EGTA $(10 \mathrm{mM})$ was added as a chelator for $\mathrm{Ca}^{++}$. Incubation was performed at $37^{\circ} \mathrm{C}$ for $5 \mathrm{~min}$, and the reaction was stopped by addition of $0.2 \mathrm{ml}$ trichloracetic acid 50\%. After centrifugation at $2,000 \mathrm{gm}$ for $15 \mathrm{~min}$, the supernatant was used to determine the inorganic phosphate concentration according to the method described by Fiske and Subbarow (1925). ATPase activity was expressed in micromoles of inorganic phosphate liberated per milligram of protein/hr.

In 1986, gill $\mathrm{Na}^{+}-\mathrm{K}^{+}$. ATPase activity increased from March to the end of May and then decreased to reach in July a value corresponding to half of the peak of the activity (Fig. 1). For ultrastructural studies, samples of fish were taken in May at the peak of the $\mathrm{Na}^{+}-\mathrm{K}^{+}$. ATPase activity; at that time, fish were ready to pass into seawater and thus were referred to as "freshwater smolts." Some of these freshwater smolts were transferred into full-strength seawater (salinity: 35\%0) for 4 days and then were sacrificed to examine the structure of the gill epithelium in "seawater smolts."

The gills of freshwater- or seawater-adapted animals were quickly dissected and treated as follows. For light microscopy, they were immersed for $16 \mathrm{hr}$ in a zinc iodide-osmium mixture (Maillet, 1959), dehydrated, and embedded in paraffin. This technique allowed the selective staining of chloride cells in black and thus facilitated their identification. For electron microscopy, gills were fixed for $1 \mathrm{hr}$ at room temperature in $1.5 \%$ glutaraldehyde buffered with sodium cacodylate, $0.05 \mathrm{M}, \mathrm{pH}$ 7.6 (for parr and freshwater smolt), or in $2 \%$ glutaraldehyde buffered with sodium cacodylate, $0.08 \mathrm{M}, \mathrm{pH} 7.6$ (for seawater smolt). In these conditions, osmolalities of the fixatives were thought to approximate the respective osmolalities of the fish plasmas in the various media (Parry, 1966).

Some glutaraldehyde-fixed filaments were immersed for $2 \mathrm{hr}$ in $0.1 \mathrm{M}$ Tris-maleate buffer containing $0.006 \mathrm{M}$ $\mathrm{MnCl}_{2}$ and $0.14 \%$ lead citrate. This technique will be referred to as "Mn-Pb staining" (Pisam et al., 1987). All fragments were postfixed for $1 \mathrm{hr}$ at room temperature 

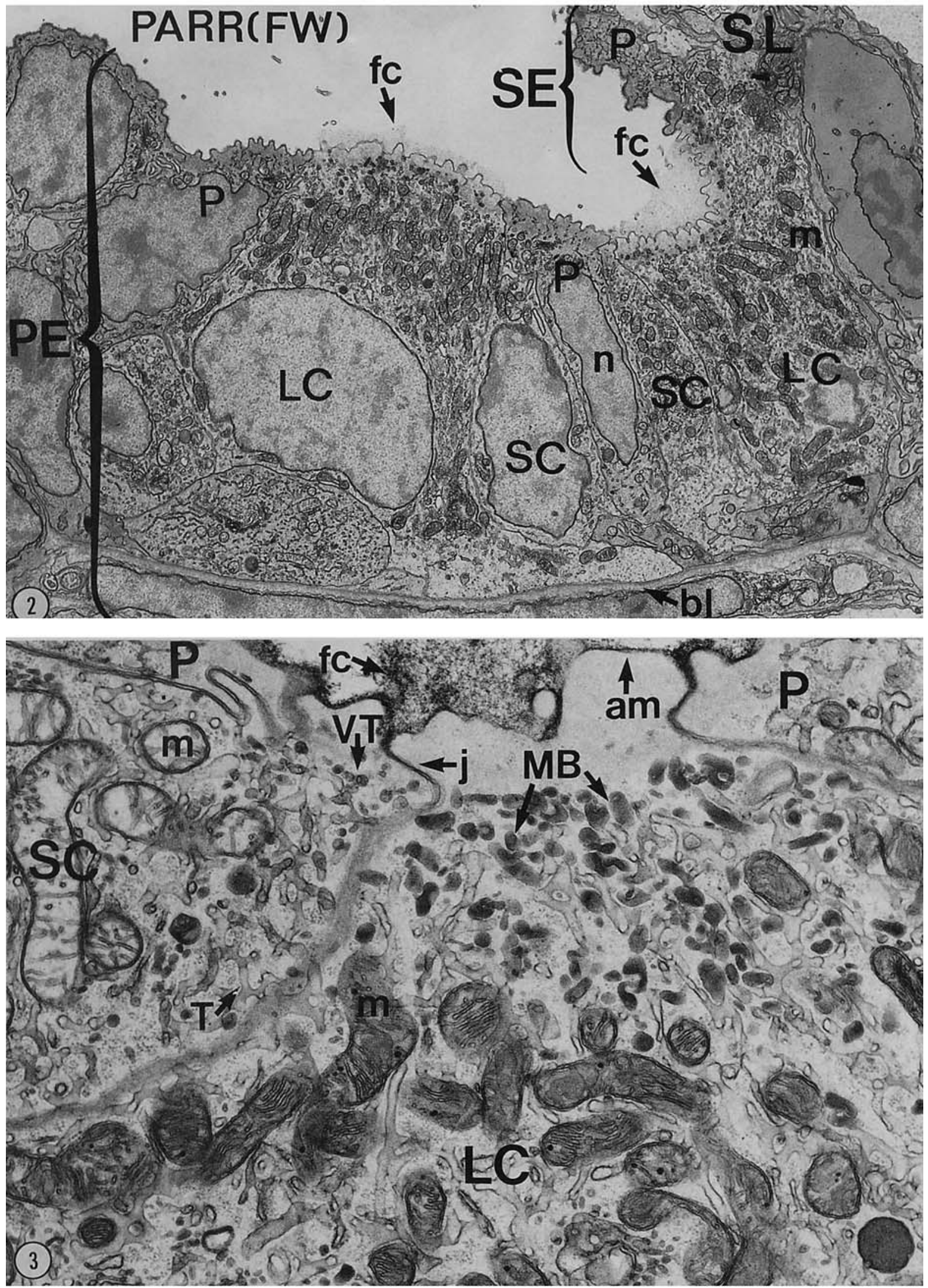

Fig. 2. Chloride cells in parr gill epithelium (reduced osmium staining). Large and small chloride cells recognizable by their numerous mitochondria are seen among pavement cells in the primary epithelium (PE). The bases of both types of chloride cells are in contact with the basal lamina (bl) of this epithelium. The apical surface of the large chloride cells is broadly exposed to the external medium and is endowed with an outspread filamentous coat (fc) which is absent from the apical surface of the other epithelial cells. The secondary epithelium $(\mathrm{SE})$ covers the free part of a secondary lamella. $\times 4500$.

Fig. 3. Apical portions of small and large chloride cells in parr gill epithelium ( $\mathrm{MnPb}$ staining). The apical parts of both types of chloride cells are attached by deep narrow junctions. At left, the small cell displays in its apical cytoplasm small vesicular and tubular elements; the tubular system is well developed. The mitochondria show few cristae and a pale matrix. In the large cell at right, the apical cytoplasm is filled with large, densely stained, membrane-bound bodies. A filamentous coat (fc) extends at some distance from the apical mem brane (am) into the external medium. The mitochondria are denser than in the small cell. $\times 26,000$. 

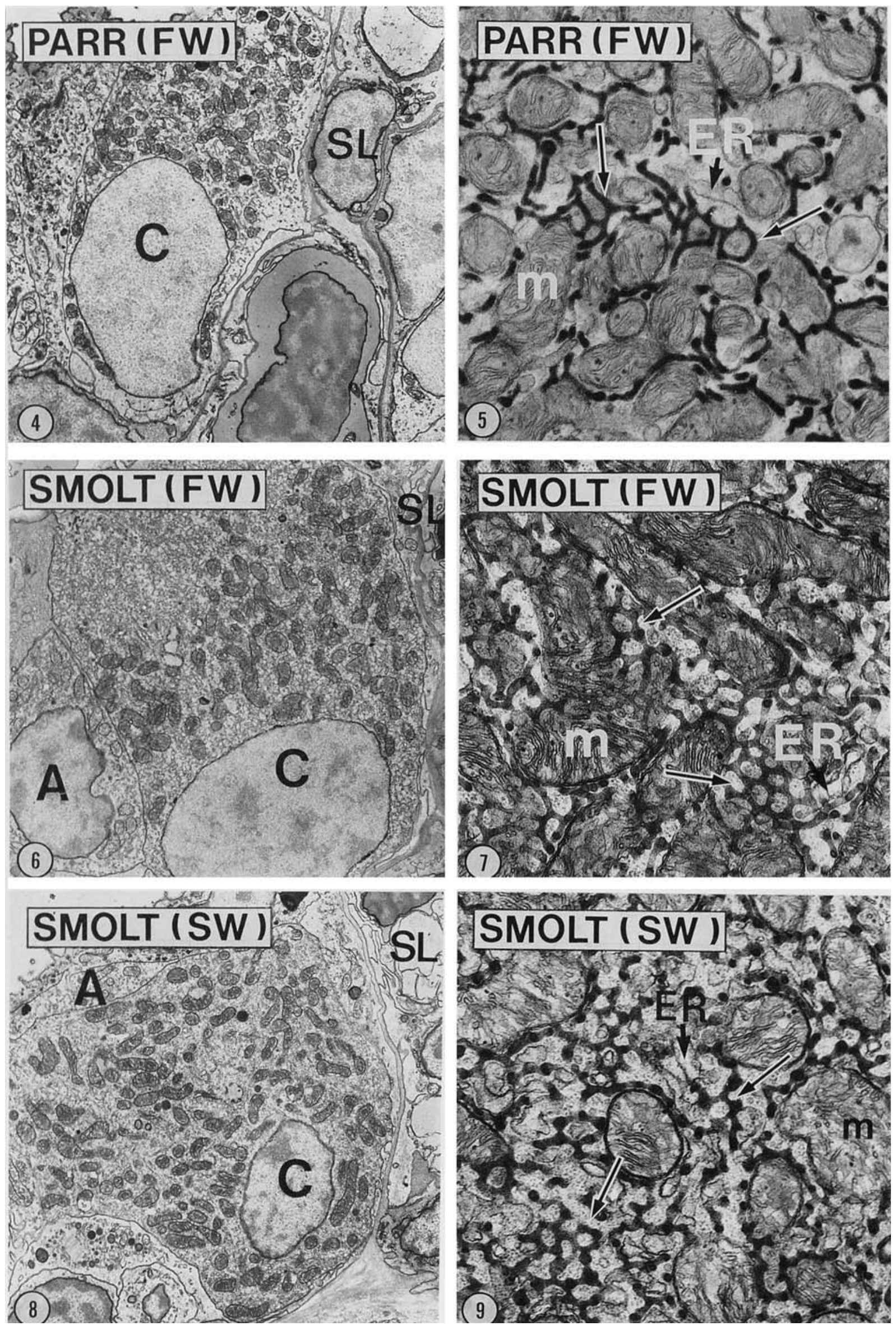
in potassium ferrocyanide-reduced osmium (Karnovsky, 1971). They were dehydrated and embedded in Epon.

Sections running parallel to the long axis of the primary lamellae and perpendicular to the secondary lamellae of the gills were poststained for $2 \mathrm{~min}$ with lead citrate and examined with a Philips EM 400 electron microscope.

The relative number of chloride cells in the gill epithelium at the three adaptive stages (parrs, freshwater, and seawater smolts) was determined in 3 fish for each stage. A counting of chloride cells in light microscopy was made on 10 portions selected at the base of the primary lamellae, each comprising 20 interlamellar spaces. Counting of the various categories of chloride cells in electron microscopy was carried out on 5 portions of primary lamellae, each including 10 interlamellar spaces.

Cell surface areas were determined on thin sections of 20 cells for each adaptive stage and calculated using a Kontron MOP-AM03 image-analysis computer (Reichert-Jung Paris) on pictures at a final magnification of $\times 5,600$.

\section{RESULTS}

The gills of salmon consist of eight branchial arches, each one of which bears primary lamellae (filaments) from which secondary lamellae radiate. By definition, the primary lamellae are covered by the primary epithelium which thus may be observed between the bases of the secondary lamellae; the secondary epithelium covers the free part of the secondary lamellae (Fig. 2). The gill epithelium contains two main cell types: the pavement cells and the chloride cells. The chloride cells are relatively voluminous cells characterized by an abundance of mitochondria and the presence, throughout their cy. toplasm, of an extensive network of membranous tubules connected with the laterobasal plasma membrane (Philpott, 1966; Kikuchi, 1977; Karnaky, 1980). This network is referred to as the tubular system (Karnaky et al., 1976a; Philpott, 1980; Pisam, 1981).

\section{Chloride Cells in Parrs}

Most of the chloride cells were located in the primary epithelium (Fig. 2), although a few also were seen in the secondary epithelium. They displayed a tubular system made up of long anastomosed tubules, which formed a loose network with wide irregular meshes (Fig. 5). Their basal membrane was usually in contact with the basal lamina of the epithelium (Fig. 2), and they were attached to adjacent epithelial cells by a deep and narrow junction that extended along a length of 400-500 nm in the apical portion of their lateral plasma membranes (Fig. 3).

Two categories of chloride cells-large and small-were identified in parrs (Figs. 2,3). The large chloride cells formed approximately $77 \%$ of the total number of chloride cells. They had a mean surface area of $139 \pm 4 \mu \mathrm{m}^{2}$ and were cuboidal. Their wide apex was endowed with a filamentous feltwork that extended for some distance into the external medium from the plasma membrane of short and wide apical microvilli (Figs. 2, 3). The elongated mitochondria were deeply stained and displayed numerous closely packed cristae within a dense matrix (Fig. 3). Numerous characteristic membrane-bound bodies showing an electron-dense content were present at the apical pole; such bodies were variable in size and shape: ovoid, elongated, or cup-shaped (Fig. 3).

The small chloride cells (23\% of the chloride-cell population) had a mean surface area of $70 \pm 18 \mu \mathrm{m}^{2}$ and were columnar. They showed a narrow apex and an apical membrane seemingly lacking filamentous material (Fig. 3). Their elongated mitochondria contained few cristae and a pale matrix and thus were distinctly paler than the mitochondria of the large chloride cells. These small chloride cells showed several small vesicles and tubules in their apical cytoplasm, but they did not contain the dense membrane-bound bodies seen in the large chloride cells (Fig. 3).

\section{Chloride Cells in Smolts and Their Relationship With Accessory Cells}

A few chloride cells were observed in the secondary epithelium of smolts maintained in fresh water; in contrast, they were totally absent from the secondary epithelium of smolts adapted to seawater. In the primary epithelium of both types of smolts, the total number of chloride cells by portion of primary lamella (including 20 interlamellar spaces) was identical to that of the parr; i.e., surveys of 10 portions of primary lamellae in three fish from each adaptive stage indicated that, on the average, there were $49.6 \pm 1.6$ chloride cells in parr, $54.2 \pm 5.2$ in freshwater smolts, and $50.6 \pm 4.2$ in seawater smolts. In contrast, the percentage of large chloride cells increased to $95 \%$ of the chloride-cell population, with a correlative decrease of the number of small chloride cells.

The large chloride cells almost doubled in size (their mean surface area increased from $139 \pm 4 \mu \mathrm{m}^{2}$ in parr to $238 \pm 50 \mu \mathrm{m}^{2}$ in freshwater smolts and $223 \pm 45 \mu \mathrm{m}^{2}$ in seawater smolts), and they assumed an ovoid shape (compare Figs. 6 and 8 with Fig. 4); the size and shape of the small chloride cells were not modified. In large chloride cells, the tubular system developed extensively to form a tight network with regular meshes distinctly smaller than those observed in parr chloride cells (Figs. 7, 9).

In addition to these chloride cells, the primary epithelium of smolts in fresh water as well as in seawater exhibited a new type of cell: the so-called "accessory cell" (Figs. 6, 8, 10-12). These cells were small, with a mean surface area of $51 \pm 10 \mu \mathrm{m}^{2}$, and their shapes varied. Their apical region contained small vesicular and tubular elements, but it was generally devoid of the large membrane-bound bodies (Figs. 10-12) observed in
Figs. 4, 6, 8. Large chloride cells in the primary epithelium (reduced osmium staining). The chloride cells located at the base of secondary lamellae are more voluminous in freshwater (Fig. 6) or seawater (Fig. 8) smolts than in parr (Fig. 4). Note the presence of accessory cells in freshwater (Fig. 6) and seawater (Fig. 8) smolts. $\times 4,000$.
Figs. 5, 7, 9. Portions of large chloride cells in which the tubular system is selectively impregnated by reduced osmium. In the parr (Fig. 5), the tubular system (arrows) forms a loose network with wide, polygonal, irregular meshes. In smolts kept in fresh water (Fig. 7) or adapted to seawater (Fig. 9), the tubular system is more tightly anastomosed than in parr; it displays numerous polygonal meshes (arrows) that are slightly smaller in seawater than in fresh water. $\times 26,000$. 

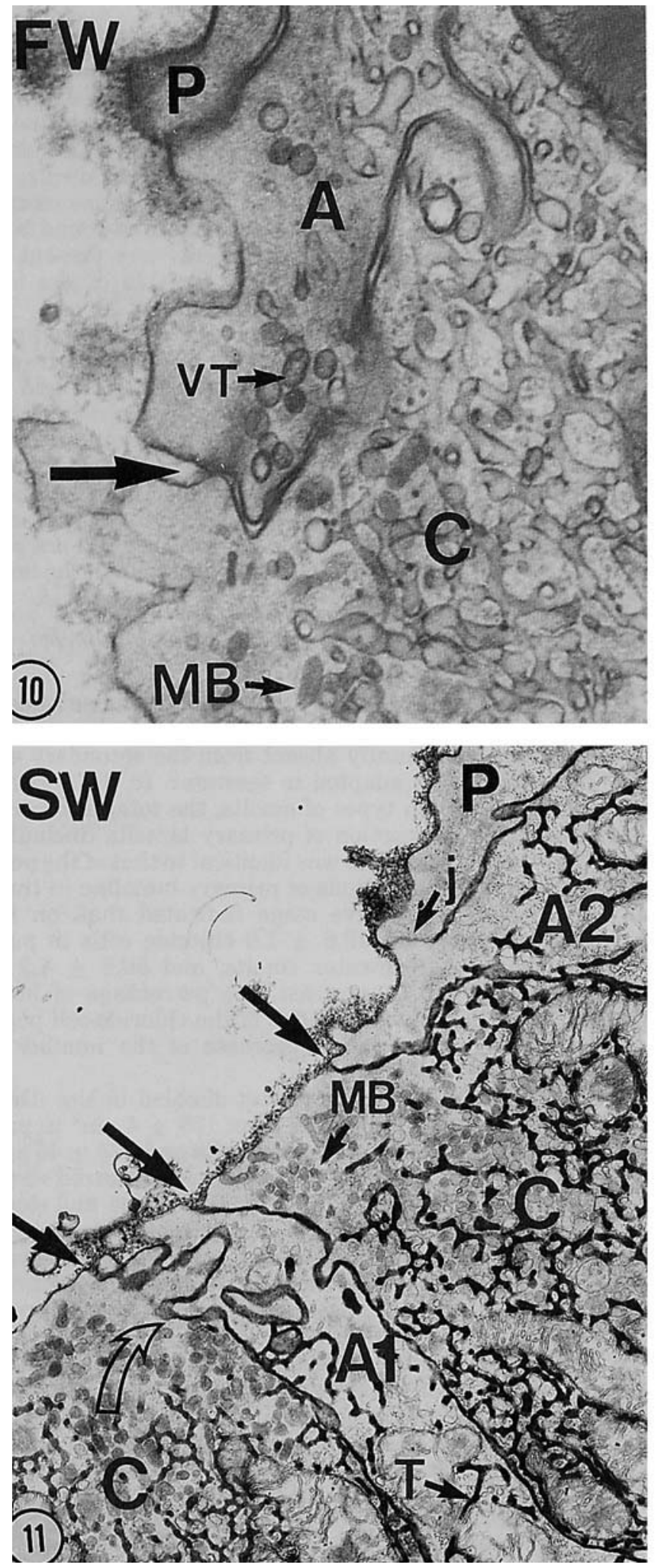

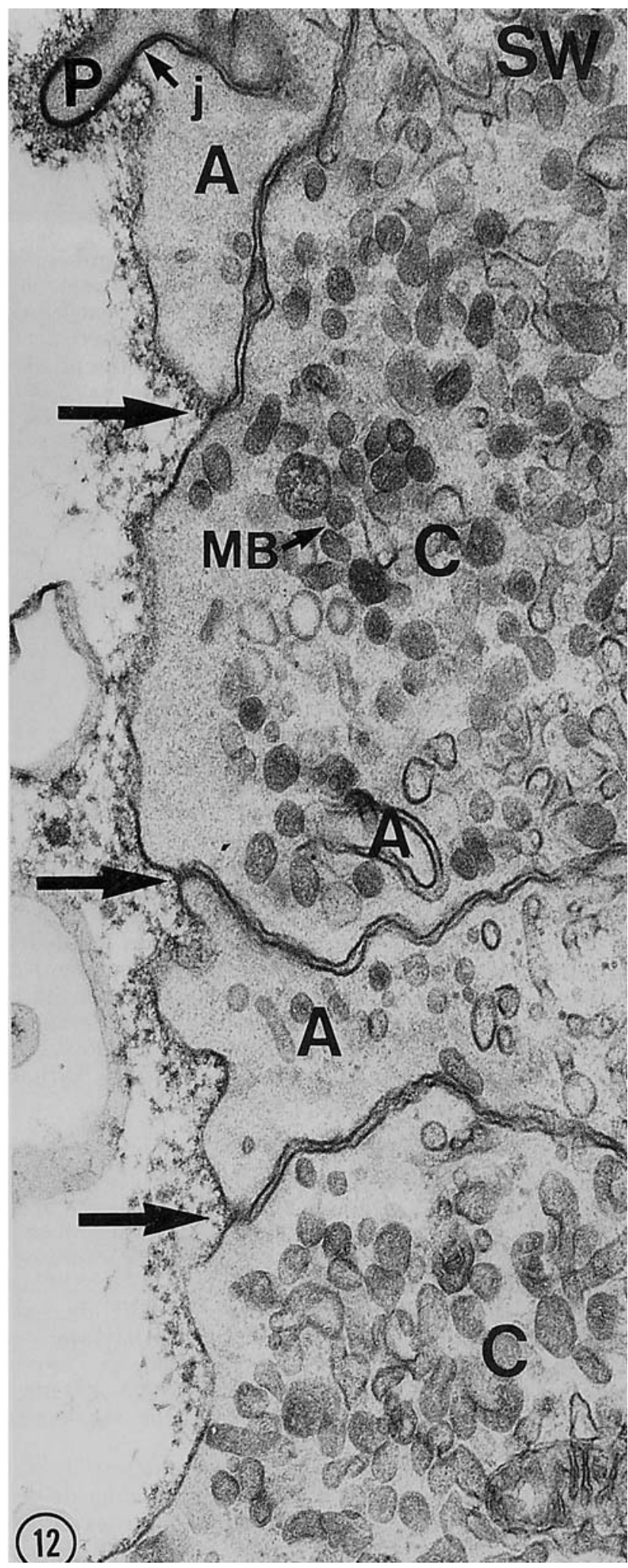

Fig. 10. Apical portions of chloride and accessory cells in freshwater smolt ( $\mathrm{Mn}$ - $\mathrm{Pb}$ staining). The accessory cell is attached to the chloride cell by one shallow junction (arrow). $\times 40,000$.

Figs. $\{1,12$. Interdigitated apical portions of chloride and accessory cells in seawater smolts.

Fig. 11. The reduced osmium staining of the tortuous intercellular space (curved arrow) separating the chloride cell from accessory cell $A_{1}$ may be followed almost up to the apical surface of the gill epithe lium (arrows); it is absent at the level of a deep narrow junction located between accessory cell $A_{2}$ and an adjacent pavement cell. Note that the apical cytoplasm of the accessory cell is devoid of the large membrane-bound bodies present in the apical cytoplasm of the chloride cell. The tubular system of the accessory cell is poorly developed in comparison with that of the adjacent chloride cell. $\times 14,000$.

Fig. 12. The upper accessory cell is attached to the adjacent pavement cell by a deep narrow junction. Three shallow junctions (straight arrows) attach accessory cells to chloride cells. Intensively stained large, membrane-bound bodies are observed exclusively in the apices of chloride cells $(\mathrm{Mn}-\mathrm{Pb})$ staining. $\times 40,000$ 
Iarge chloride cells. Their tubular system was less developed (Fig. 11). These accessory cells were invariably adjacent to chloride cells, to which they were attached by shallow apical junctions (30-40 $\mathrm{nm}$ in length). In contrast, the chloride cells or the accessory cells always were linked to adjacent pavement cells by deep, seemingly tight junctions (Figs. 11, 12).

In freshwater smolts, only $40 \%$ of the large chloride cells were endowed with accessory cells, half of which were not seen in contact with the external medium (Fig. 6). In contrast, in seawater-adapted smolts, the percentage of large chloride cells associated with accessory cells increased to $80 \%$. Most of these accessory cells reached the external medium; furthermore, they sent numerous cytoplasmic interdigitations into the apex of the adjacent chloride cells, thus making with the latter a mosaic of interlocked apical cell processes bound together by shallow apical junctions (Figs. 11, 12).

\section{DISCUSSION}

The heterogeneity of the chloride-cell population in the gill epithelium of euryhaline freshwater teleosts has been noted by several investigators (Doyle and Gorecki, 1961; Straus, 1963; Bierther, 1970; Shirai and Utida, 1970; Richman et al., 1987). Thus, in the guppy kept in fresh water, two types of chloride cells-the $\alpha$ and $\beta$ cells-have been clearly distinguished on the basis of their location, shape, and cytoplasmic features (Pisam et al., 1987). In the present study, two types of chloride cells have also been identified in parrs: the large and small chloride cells. The large chloride cells obviously resemble the $\beta$-chloride cells described in the gill epithelium of freshwater guppies. Like the latter cells, they are ovoid and display in their apical cytoplasm a system of large, irregular, membrane-limited bodies. The small chloride cells, in contrast, might be mistaken for accessory cells, which sometimes have been reported in freshwater euryhaline fish (Karnaky, 1986; Chretien and Pisam, 1986). In the Atlantic salmon, however, accessory cells appear only in smolts. In these fish, they always are found in close apposition to the apical portion of the lateral surface of a chloride cell to which they are bound by shallow junctions; they never reach the basal lamina of the gill epithelium. The situation of the small cells in parrs is clearly different. They are usually located at some distance from the large chloride cells and are in contact with the basal lamina by small portions of their basolateral surfaces. Furthermore, their tubular system is almost as elaborate as that in the large cells and thus differs markedly from the somewhat rudimentary network depicted in accessory cells. The small cell, therefore, should be considered as a second type of chloride cell, clearly distinct from the accessory cell. The functional significance of this small chloride cell, found mainly in parrs, is unknown at present. Threadgold and Houston (1964) also described in the freshwater parr of the Atlantic salmon a small cell located next to a large chloride cell that closely resembles the small chloride cell depicted in the present study, which they called a "replacement cell." Whether this is the case or whether the small cell is another functional type of chloride cell remains to be established.

Freshwater smolts display gill epithelium structures which, in euryhaline fish, are found only in seawater- adapted animals. Thus, chloride cells increase in volume and develop an extensive, tightly meshed network of membranous tubules continuous with the basolateral plasma membrane (Fig. 13). As the $\mathrm{Na}^{+}-\mathrm{K}^{+}$-ATPase usually is considered to be located on the membranes of the tubular system (Karnaky et al., 1976b; Hootman and Philpott, 1979), this increase in surface area of the membranous system may be regarded as the ultrastructural counterpart of the increase in $\mathrm{Na}^{+}-\mathrm{K}^{+}$-ATPase activity reported during smoltification (Zaugg and McLain, 1970; McCartney, 1976; Saunders and Henderson, 1978; Folmar and Dickhoff, 1979, 1981; Boeuf and Prunet, 1985; Boeuf et al., 1985; Fig. 1). Another modification also observed in freshwater smolts and usually thought to be specific to seawater adaptation is the concomitant appearance of accessory cells and their linkage to the apical portions of chloride cells by shallow junctions (Hootman and Philpott, 1980; Lacy, 1983; Chretien and Pisam, 1986). Thus, it is clear that during smoltification, while still in fresh water, the Atlantic salmon undergoes structural transformations that are preparatory to its entry into a hyperosmotic environment. Consequently, in contrast to most euryhaline fish, which cannot be adapted to seawater without a transient disruption of their hydromineral balance, freshwater smolts can immediately regulate this balance, even in such drastic conditions as a direct transfer to seawater (35\%0) (Prunet and Boeuf, 1985).

Transfer of freshwater smolts into seawater increases the number of accessory cells and induces the development of extensive plasma membrane interdigitations between these cells and enlarged chloride cells (Fig. 13). As a result, there is a concomitant amplification of the length of the shallow junction sealing off the apical part of this expanded intercellular space. Such a phenomenon may occur at a surprisingly quick rate, as has been shown by Hwang and Hirano (1985) that the development of interdigitations and leaky junctions between chloride and accessory cells could be observed as soon as $3 \mathrm{hr}$ after transfer of juveniles of ayu, carp, and flounder into seawater. Such an ultrastructural modification may have a crucial role in the seawater adaptation of freshwater fish. Indeed, Sardet et al. (1979) noted that in the gills of various species of teleostean fish, a fundamental reorganization of chloride cells was associated with seawater adaptation. The apices of chloride cells formed, with their associated accessory cells, a mosaic of cells linked to surrounding pavement cells by deep apical junctions, which appeared multistranded when examined by freeze-fracture microscopy. In contrast, the chloride cells were linked to the accessory cells by shallow, single-stranded junctions permeable to lanthanum. Such junctions also were observed in the low-resistance, chloride-secreting opercular epithelium of the seawateradapted killifish (Ernst et al., 1980), in the electrolytesecreting epithelium of the avian salt gland (Ellis et al., 1977; Riddle and Ernst, 1979), and in the salt-secreting epithelium of elasmobranch rectal glands (Ernst et al., 1979). In all these cases, as in the gill epithelium, the apical surfaces of adjacent electrolyte-secreting cells were narrow and highly interdigitated. Hence, the shallow and presumably leaky junctions exhibited a marked tortuosity. It was proposed that they could provide a paracellular pathway for ions secreted in seawater (Sardet et al., 1979; Ernst et al., 1980; Forrest et al., 1982). 

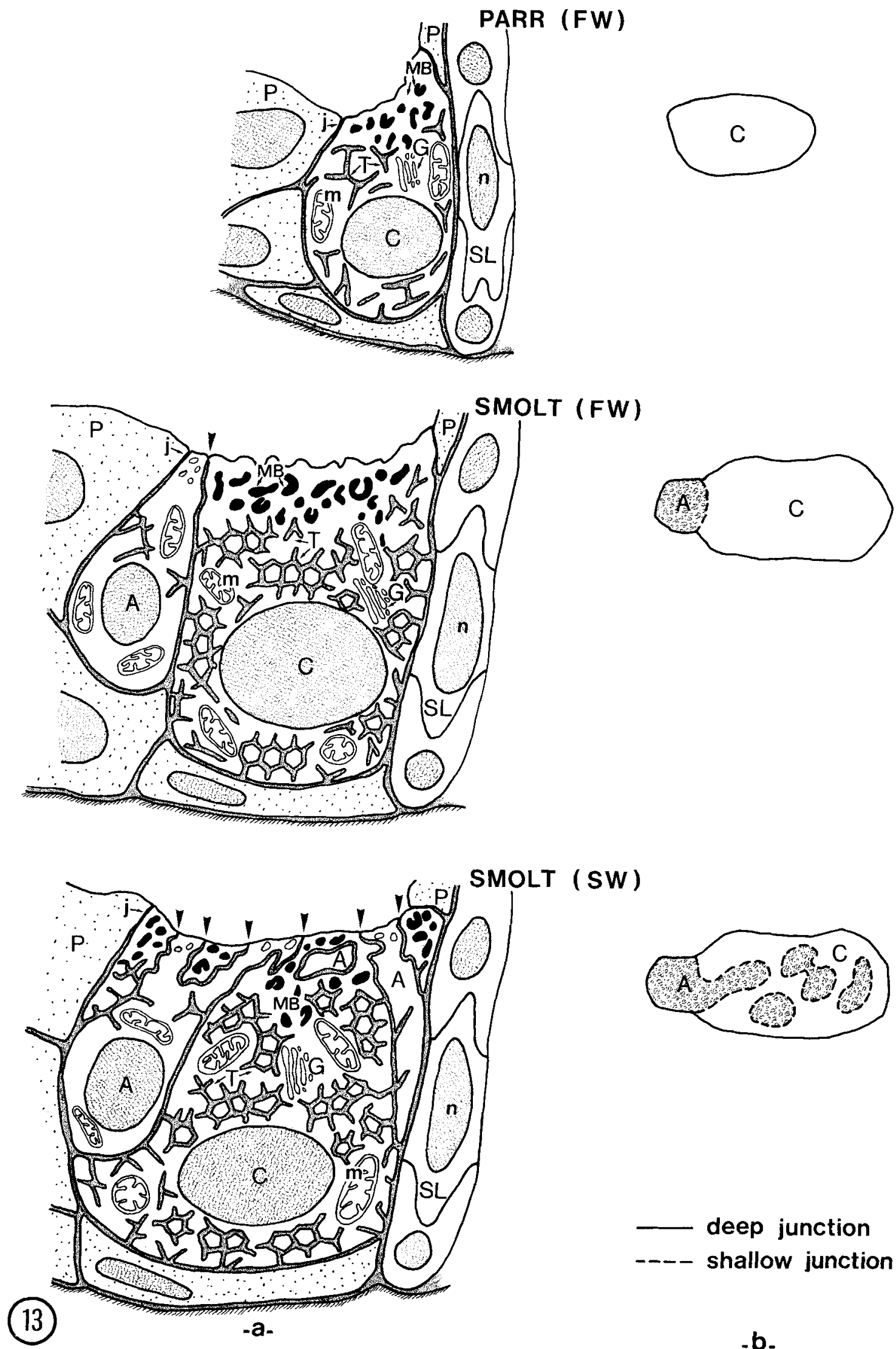

-b. 
It is concluded that, in contrast to most euryhaline fish, the Atlantic salmon in freshwater may promote in its gill epithelium most of the structural transformations required for its survival in a hyperosmotic environment. Indeed, the enlargement of the chloride cells with their extensive tubular system and the appearance of accessory cells are not triggered by seawater, but rather may result from a complex synergy between external (temperature, photoperiod, trophic capacity of the external medium) and internal (endocrine, nervous) factors (Saunders and Henderson, 1970; Fontaine, 1975; Hoar, 1976; Komourdjan et al., 1976; Wedeweyer et al., 1980; Folmar and Dickhoff, 1980). Among different hormones, cortisol has been reported to have an important role in controlling ultrastructural transformations in the eel, Anguilla rostrata (Doyle and Epstein, 1972). However, recent studies on Atlantic salmon smolts (Langdon et al., 1984; Langhorne and Simpson, 1986) do not support the role of cortisol in the development of hypoosmoregulatory ability. Further studies are required to clarify the nature of the agents responsible for the ultrastructural transformations observed in freshwater smolts. The effective transfer into seawater, which induces amplification of the length of the shallow junction sealing the intercellular space between chloride and accessory cells, would then act as a final stimulus to achieve some adequacy between the freshwater smolt and its new hyperosmotic environment.

\section{ACKNOWLEDGMENTS}

We wish to thank Dr. J.M. Nance for quantitation in light microscopy. We also would like to express our gratitude to Professors Y. Clermont, H. Bern, and M. Bornancin for their critical reading of the manuscript. The drawings were prepared by P. Teyton (Fig. 1) and M. Lucarain (Fig. 13).

\section{LITERATURE CITED}

Bierther, M. 1970 Die Chloridzellen des Stichlings. Z. Zellforsch., 107: $421-446$.

Fig. 13. Schematic representation of the ultrastructural modifications of large chloride cells and accessory cells in the gill epithelium of the Atlantic salmon during smoltification, as seen in sections perpendicular to the surface of the epithelium (a) and running parallel to the surface of the epithelium near the apical surface of the cells (b).

In parr, the chloride cell contains a well-developed tubular system connected with its basolateral plasma membrane; numerous irregular dense bodies are present in the apex. The apical portion of the chloride cell is bound to adjacent pavement cells by deep, narrow, presumably tight junctions.

In the freshwater (FW) smolt, the chloride cell increases in size. Its tubular system has developed to form a tightly meshed network. The apical portion of its lateral surface is now seen in contact with an accessory cell. The intercellular space between the chloride cell and the accessory cell is sealed off from the external medium by a shallow, presumably "leaky" junction (arrowhead), easily distinguished from the deep, tight junctions binding chloride and accessory cells to pavement cells.

In the seawater (SW) smolt, the apical portions of the chloride and accessory cells are highly interdigitated. As a result, the apex of the chloride cell forms with its associated accessory cell a mosaic of cell processes linked together by a tortuous shallow junction (arrowheads). The cell complex is still bound to the surrounding pavement cells by deep, tight junctions.
Boeuf, G, and P. Prunet 1985 Measurements of gill $\mathrm{Na}^{+} \mathrm{K}^{+}$ATPase activity and plasma thyroid hormones during smoltification in atlantic salmon Salmo salar L. Aquaculture, 45:111-119.

Boeuf, G., P. Lasserre, and Y. Harache 1978 Osmotic adaptation of Oncorhynchus kisutch Walbaum. II. Plasma osmotic and ionic variations and gill $\mathrm{Na}^{+}, \mathrm{K}^{+}$adenosine triphosphatase activity of yearling coho salmon, transferred to sea water. Aquaculture, 15:35-52.

Boeuf, G., A. Le Roux, J.L. Gaignon, and Y. Harache 1985 Gill ( $\mathrm{Na}^{+}$. $\mathrm{K}^{+}$)-ATPase activity and smolting in atlantic salmon Salmo salar L. in France. Aquaculture, 45:73-81.

Chretien, M., and M. Pisam 1986 Cell renewal and differentiation in the gill epithelium of fresh- or salt-water-adapted euryhaline fish as revealed by ${ }^{3} \mathrm{H}$-thymidine radioautography. Biol. Cell, 56:137150.

Doyle, W.L., and F.H. Epstein 1972 Effects of cortisol treatment and osmotic adaptation on the chloride cells in the eel Anguilla rostrata. Cytobiologie, 6:58-73.

Doyle, W.L., and D. Gorecki 1961 The so-called chloride cell of the fish gill. Physiol. Zool., 34:81-85.

Dunel-Erb, S., and P. Laurent 1980 Uitrastructure of marine teleost gill epithelia: SEM and TEM study of the chloride cell apical membrane. J. Morphol., 165:175-186.

Ellis, R.A., C.C. Goertemiller, Jr,, and D.L. Stetson 1977 Significance of extensive "leaky" cell junctions in the avian salt glands. Nature, 268:555-556

Ernst, S.A., S.R. Hootman, J.H. Schreiber, and C.V. Riddle 1979 Structure of occluding junctions in the salt secreting epithelium of elasmobranch rectal gland. J. Cell Biol., 83:83a.

Ernst, S.A., W.C. Dodson, and K.J. Karnaky 1980 Structural diversity of occluding junctions in the low resistance chloride secreting oper. cular epithelium of sea water adapted killifish (Fundulus heteroclitus) J. Cell Biol., 87:488-497.

Fiske, E.H., and Y.V. Subbarow 1925 The colorimetric determination of phosphorus. Biol. Chem., 66:375-400.

Folmar, L.C., and W.W. Dickhoff 1979 Plasma thyroxine and gill $\mathrm{Na}^{+}$ $\mathrm{K}^{+}$ATPase changes during sea water acclimation of coho salmon Oncorhynchus kisutch. Comp. Biochem. Physiol., 63A:329-332.

Folmar, L.C., and W.W. Dickhoff 1980 The parr-smolt transformation (smoltification) and sea water adaptation in salmonids. A review of selected literature. Aquaculture, 21:1-37.

Folmar, L.C., and W.W. Dickhoff 1981 Evaluation of some physiological parameters as predictive indices of smoltification. Aquaculture, 23:309-324

Fontaine, M. 1975 Physiological mechanisms in the migration of marine and amphihaline fish. Adv. Marine Biol., 13:241-355.

Forrest, J.N., Jr., J.L. Boyer, T.A. Ardito, H.V. Murdaugh, and J.B. Wade 1982 Structure of tight junctions during $\mathrm{Cl}$ secretion in the perfused rectal gland of the dogfish shark. Am. J. Physiol., 242: C388-C392.

Hoar, W.S. 1976 Smolt transformation: evolution, behaviour, and physiology. J. Fish. Res. Board Can., 33:1234-1252.

Hootman, S.R., and C.W. Philpott 1979 Ultracytochemical localisation of $\mathrm{Na}^{+}, \mathrm{K}+$, activated ATPase in chloride cells from the gills of a euryhaline teleost. Anat. Rec., 193:99-130.

Hootman, S.R., and C.W. Philpott 1980 Accessory cells in teleost branchial epithelium. Am. J. Physiol., 238:R199-R206.

Hwang, P.P., and R. Hirano 1985 Effects of environmental salinity on intercellular organization and junctional structure of chloride cells in early stages of teleost development. J. Exp. Zool., 236:115-126.

Karnaky, K.J., Jr. 1980 Ion secreting epithelia: chloride cells in the head region of Fundulus heteroclitus. Am. J. Physiol., 238:R185R198.

Karnaky, J.J., Jr. 1986 Structure and function of the chloride cell of Fundulus heteroclitus and other teleosts. Am. Zool., 26:209-224.

Karnaky, K.J., Jr, S.A. Ernst, and C.W. Philpott 1976a Teleost chloride cell. I. Response of pupfish Cyprinodon variegatus gill Na, K-ATPase and chloride cell fine structure to various high salinity environments. J. Cell Biol., 70:144-156.

Karnaky, K.J., Jr., L.B. Kinter, W.B. Kinter, and C.E. Stirling 1976b Teleost chloride cell. II. Autoradiographic localization of gill Na, K-ATPase in killfish Fundulus heteroclitus adapted to low and high salinity environments. J. Cell Biol., 70:157-177.

Karnovsky, M.J. 1971 Use of ferrocyanide reduced osmium tetroxide in electron microscopy. Proc. 11th Am. Soc. Cell Biol., New Orleans, Abstract 284, p. 146.

Keys, A.B., and E.N. Willmer 1932 "Chloride secreting cells" in the gills of fishes with special reference to the common eel. J. Physiol. (London), 76:368-378.

Kikuchi, S. 1977 Mitochondria rich (chloride) cells in the gill epithelia from four species of stenohaline fresh water teleosts. Cell Tiss. Res., 180:87-98. 
Komourdjian, M.P., R.L. Saunders, and J.C. Fenwick 1976 Evidence for the role of growth hormone as a part of a "light pituitary axis" in growth and smoltification of atlantic salmon Salmo salar $\mathbf{L}$. Can. J. Zool., 54:544-551.

Lacy, E.R. 1983 Histochemical and biochemical studies of carbonic anhydrase activity in the opercular epithelium of the euryhaline teleosts, Fundulus heteroclitus. Am. J. Anat., 166:19-39.

Langdon, J.S., J.E. Thorpe, and R.J. Roberts 1984 Effect of cortisol and ACTH on gill $\mathrm{Na}^{+} \cdot \mathrm{K}^{+}$. ATPase, SDH and chloride cells in juvenile Atlantic salmon Salmo salar. Comp. Biochem. Physiol., 77A:9-12.

Langhorne, P., and T.H. Simpson 1986 The interrelationship of cortisol, gill $\mathrm{Na}^{+}-\mathrm{K}^{+}$-ATPase and homeostasis during the parr smolt transformation of Atlantic salmon Salmo salar L. Gen. Comp. Endocrinol., 61:203-213.

Lasserre, P., G. Boeuf, and Y. Harache 1978 Osmotic adaptation of Oncorhynchus kisutch Walbaum. I. Seasonal variations of gill $\mathrm{Na}^{+}$. $\mathrm{K}^{+}$-ATPase activity in coho salmon, 0 age and yearling, reared in freshwater. Aquaculture, 14:365-382.

Laurent, P., and S. Dunel 1980 Morphology of gill epithelia in fish. Am. J. Physiol., 238:R147-R159.

Maetz, J. 1971 Fish gills: mechanisms of salt transfer in fresh water and sea water. Philos. Trans. R. Soc. Lond. (Biol.), 262:209-251.

Maillet, M. 1959 Modifications de la technique de Champy au tetroxyde d'osmium-iodure de potassium. Resultats de son application à l'étude des fibres nerveuses. C. R. Sac. Biol, 153:939-940.

McCartney, T.H. 1976 Sodium-potassium dependent adenosine triphosphatase activity in gills and kidneys of atlantic salmon Salmo salar L. Comp. Biochem. Physiol., 53A:351-353.

Parry, G. 1966 Osmotic adaptation in fishes. Biol. Rev., 41:392-444.

Philpott, C.W. 1966 The use of horseradish peroxidase to demonstrate functional continuity between the plasmalemma and the unique tubular system of the chloride cell. J. Cell Biol., 31:86A (abstract).

Philpott, C.W. 1980 Tubular system membranes of teleost chloride cells: Osmotic response and transport sites. Am. J. Physiol., 238. R171-R184.

Philpott, C.W., and D.E. Copeland 963 Fine structure of chloride cells from three species of Fundulus J. Cell Biol., 18:389-404.

Pisam, M. 1981 Membranous systems in the "chloride cell" of teleostean gill: Their modifications in response to the salinity of the environment. Anat. Rec., 200:401-414.
Pisam, M., A. Caroff, and A. Rambourg 1987 Two types of chloride cells in the gill epithelium of a freshwater-adapted euryhaline fish: Lebistes reticulatus; their modifications during adaptation to salt water. Am. J. Anat., 179:40-50.

Prunet, P., and G. Boeuf 1985 Plasma prolactin level during transfer of rainbow trout (Salmo gardneiri) and Atlantic salmon (Salmo salar L.) from fresh water to sea water. Aquaculture, 45:167-176.

Richman, N.H., S.T. de Diaz, R.S. Nishioka, P. Prunet, and H.A. Bern 1987 Osmoregulatory and endocrine relationships with chloride cell morphology and density during smoltification in coho salmon (Oncorhynchus kisutch). Aquaculture, 60:265-285.

Riddle, C.V., and S.A. Ernst 1979 Structural simplicity of the zonula occludens in the electrolyte secreting epithelium of the avian salt gland. J. Membr. Biol., 45:21-35.

Sardet, C., M. Pisam, and J. Maetz 1979 The surface epithelium of teleostean fish gills. J. Cell Biol., 80:96-117.

Saunders, R.L., and E.B. Henderson 1978 Changes in gill ATPase activity and smolt status of atlantic salmon Salmo salar. J. Fish. Res. Bd Can., 35:1542-1546.

Saunders, R.L., and E.B. Henderson 1978 Changes in gill APTase activity and smolt status of atlantic salmon Salmo salar. J. Fish. Res. Bd Can., 35:1542-1546.

Shirai, N., and S. Utida 1970 Development and degeneration of the chloride cell during sea water and fresh water adaptation of the Japanese eel: Anguilla japonica. Z. Zellforsch., 103:247-264.

Straus, L.P. 1963 A study of the fine structure of the so-called chloride cell in the gill of the guppy Lebistes reticulatus P. Physiol. Zool. $36: 183-198$.

Thorpe, J.E., L. Talbot, and C. Villarreal 1982 Bimodality of growth and smolting in Atlantic salmon Salmo salar L. Aquaculture, 28: 123-132.

Threadgold, L.T., and A.H. Houston 1964 An electron microscope study of the "chloride cell" of Salmo salar L. Exp. Cell Res, 34:1-23.

Wedeweyer, G., R.L. Saunders, and W.L. Clarke 1980 Environmental factors affecting smoltification and early marine survival of anadromous salmonids. Mar. Fish. Rev., 42:1-14.

Zaugg, W.S., and L.R. McLain 1970 Adenosine triphosphatase activity in gills of salmonids: seasonal variations and salt water influence in coho salmon Oncorhynchus kisutch. Comp. Biochem. Physiol. 35:587-596. 